\title{
Adoption Level of Sustainable Construction Practices: A Study on Malaysia's Construction Stakeholders
}

\author{
Wan Nadzri Bin Osman ${ }^{1}$, Zulkifli Mohamed Udin ${ }^{1}$ and Dani Salleh ${ }^{2}$ \\ ${ }^{1}$ School of Technology Management and Logistics, UUM College of Business, \\ Universiti Utara Malaysia \\ ${ }^{2}$ School of Government, UUM College of Law Government and International Studies, \\ Universiti Utara Malaysia
}

\begin{abstract}
Purpose - For this research, the concept of sustainability had been divided into two different perspectives which include the financial sustainability performance (economics aspect) and non financial sustainability performance (environment and social aspect).

Design/methodology/approach - A survey method was employed due to the reason that it is the most appropriate research design to obtain personal and social facts, beliefs, and attitude on a large scale. Since the data of analysis is done at the company level, the unit of analysis for this research is the construction stakeholder's organization.
\end{abstract}

Findings - The result of this study shows that the adoption level of financial sustainability is better than non financial sustainability.

Originality / value - This paper attempts to identify the current level of sustainable construction performance among the Malaysian construction stakeholders.

Keywords: Construction industry, Sustainable Development, Sustainable Construction.

\section{Introduction}

Various organisations, researchers and stakeholders have put forward definitions of the construction industry that depends on their individual points of view and goals. The definition of construction industry can be broadly divided in narrow and broad definitions.

According to Bakkens (2003), construction industry could be considered as 'the professional firms and organisations (and their representative associations) contributing to the development, maintenance, management and demolition/deconstruction of buildings and other construction making up the built environment.'

Construction sector is also defined as the activity involving creation of physical infrastructure, superstructure, housing and other related facilities. According to Wells (1986), the construction sector comprises all civil engineering works and new building projects. The construction sector is also defined as "the sector that plans, organizes and produces building and civil engineering projects." Construction activities refer to a wide range of activities, such as buildings work, hydraulics, airports, railways, highways, bridges, dredging harbours, dock-work, sewage article distributed under the Creative Commons Attribution License unported 3.0, which permits unrestricted use, distribution, and reproduction in any medium, provided that original work is properly cited. Contact author: Wan Nadzri Bin Osman E-mail: wannadzri@uum.edu.my 
treatment facilities, tunnelling and demolition activities. The construction industry is generally characterised by physically large and expensive products, separation of design from construction, powerful' clients, extensive specialisation, delivery of products at the clients premises, bespoke designs, usually without prototype models or precedents to provide guidance, risky and uncertainty (Harvey and Ashworth,1997).

\section{Construction Industry and Its Impact}

Construction activities are considered as a major contributor to environmental pollution (Augenbroe and Pearce, 1998). This sector consumes huge portions of raw materials (Ding, 2005). The impact of construction sector is produces undesirable remnants which includes (a) depletion of non-renewable resources, (b) destruction of landscapes and (c) creation of health and safety problem both relating directly \& indirectly to the people involved with the construction industry (Azapagic, 2004).

The environmental costs resulting from the construction process is substantial (Ofori, 1992). Much energy is used in the production of materials such as cement, steel,wood, transportation of materials and components to sites, operating of plant and machineries on site. The construction process results in waste, which in turn results in, inter alia, the waste of land resources and the contamination of natural resources and ecologies. The construction industry accounts for nearly 40 percent of the material flow compared to other sector (Roodman and Lenssen, 1995) and in developing countries, it consumes about 50 percent of the total energy consumption (Levin, 1997). The construction industry also has been estimated to account for 30 to 40 percent of the total energy consumed in many countries (Macozoma, 2001).

The construction sector has a negative image mainly as a result of the industry's failure to change the attitudes, processes, technologies and cultures. As mentioned above, these problems has led to the issues of natural resource depletion, accumulation of waste and environmental degradation (Watuka and Jennifer, 2002). To increase the consideration to Sustainable Construction (SC), the construction stakeholders especially the clients, consultants and contractors must be willing to change their attitudes and culture in exploring new territory and willing to adopt new ideas and practices (Ofori et.al, 2000). Regarding to these issues, construction sector becomes priority in todays development programmes which aimed at improving the quality of life and contributing towards the formation of a caring society. However, the issues of SC are still new and not that familiar in especially in Malaysia. In general, the process of driving sustainability in Malaysian construction industry is slow (Shafii and Othman, 2005). Referring back the construction projects in the past decade, those previous projects were not meeting the essential criteria of SC. According to Mobey and Parker (2002), to increase the chances of a project succeeding, it is necessary for the construction players to have better understanding of what are the success factors. According to Maylor H. (1999), the organisations that are most resourceful in seeking out best practices will be the most successful.

\section{The Concept of Sustainable Development in Construction Industry}

Sustainable Development (SD) is important for management and protection of the environment (Ding, 2008). The issues of SD deals with a wide range of factors within the local and global level making SD a common issue to different business sector (Azapagic, 2003), which in turn poses differences in practices of work often seen in many cases (Gloet, 2006). The SD challenge is the long-term challenge which need to be faced by the human race (Blair, 2006). According to Liddle (1994), those who take a SD approach to design and construction will be rewarded with reduced liability, new markets, and an earth-friendlier construction process, which will help future and current generations to achieve a better quality of life. According to World Commission on 
Environment and Development (WCED), led by the Norwegian Prime Minister Gro Harlem Brundtland, a general concept of SD was put forward as the development which "meets the needs of the present without compromising the ability of future generations to meet their own needs" (WCED,1987). Since then, the definition of SD has evolved. The WCED asserts that sustainable development requires the simultaneous adoption of three themes which include environmental quality, economic prosperity and social equity (Bansal, 2005) and the loss of one dimension is likely to mean the loss of another. According to Henriques (2001), environmental and economic gain should also lead to social gain.

\section{Sustainable Construction}

The concept of SC was proposed to describe the responsibility of the construction sector in the attainment of overall project sustainability (Henriques, 2001). Since then, SC has been defined in various ways with various implications. Hill and Bowen (1997) defines SC as a special case of SD targeting the specific group of construction industry. This group tasks are to develop, plan, design, construct, operate, and maintain the built environment. According to Lanthing (1995), SC can be defined as a construction process which incorporates the basic themes of SD. SC processes would thus bring environmental responsibility, social awareness, and economic profitability objectives to in all construction project stages (Parkin, 2000). Raynsford (2000) mentioned that SC within the context of the construction sector as construction that created a healthy built environment through resource efficiency and ecologically based principles. SC can also be defined as a construction process which incorporates the basic themes of SD (Kibert, 2005). Chaharbaghi and Wills (1999)defined SC as " $a$ holistic process aiming to restore and maintain harmony between the natural and built environments, and create settlements that affirm human dignity and encourage economic equity". Plessis (2002) explains $\mathrm{SC}$ as directed towards the reduction of the environmental and health impacts consequent to construction sector and the built environment.

\section{Research Objectives}

The objective of this study is to identify the current level of sustainability performance in the Malaysian construction industry among the local stakeholders. For this research, the concept of sustainability had been divided in two different perspectives which include the financial sustainability (economics aspect) and non financial sustainability (environment and social aspect).

\section{Research Methodology}

The sample of this study was determined using simple random sampling technique. This type of sample is most suitable where every element in the population has a known and equal chance of being selected as a subject. In other word, each single of element in the list has the same or equal probability of being chosen.

The quantitative research was carried out and the main respondents were the Malaysia's local construction stakeholders. Previous researchers who carried out research in the sustainable development assessment frameworks suggested that the following stakeholders are crucial in attaining construction sustainability which include the Consultants (architects, quantity surveyors and engineers), Contractors (manifesting the design into reality), and the Clients (the ones who drive the sustainability needs of the projects). The numbers of questionnaires received were 94. However, only 88 questionnaires were usable out of the total responds.

\section{Data Analysis}

The level of sustainability performance in Malaysian construction industry is presented in Tables 1.2 and 1.3 below. Each table represent each category of factors which include the financial sustainability and non financial sustainability rated on a scale of 1 to 4 . The most agreed for each factor was scored on a scale of 1 to 4 with 1 
having the least agreed and 4 having the most agreed. To identify the criticality index for each factor, the factor criticality was defined as in the Table 1.1 below.

Table 1.1 : Criticality Assessment Criteria

\begin{tabular}{|c|c|c|}
\hline $\begin{array}{c}\text { Mean Factor Score } \\
\text { Range }\end{array}$ & Criticality Index & Criticality Level \\
\hline$<2.0$ & 1 & Least Agreed \\
\hline$>2.0-3.0$ & 2 & Mildly Agreed \\
\hline$>3.0-3.5$ & 3 & Moderately Agreed \\
\hline$>3.5-4.0$ & 4 & Mostly Agreed \\
\hline
\end{tabular}

\section{Financial Sustainability Performance}

The highest mean score for financial sustainability for the whole data set as perceived by the construction stakeholders is 3.2045 where the respondents believed that most of their projects had improved the used of local resources. The minimum scores is 3.0227 where the respondents believed that most of their projects are adaptable within the minimum cost. In term of critically index, all of the items can be categorised at moderate level. Overall mean for the whole data set is 3.1105, which could be considered at moderate level.

Table 1.2 - Mean Analysis for Financial Sustainability Performance

\begin{tabular}{|c|c|l|}
\hline $\begin{array}{c}\text { Mean Factor Score } \\
\text { Range }\end{array}$ & Criticality Index & \multicolumn{1}{c|}{ Items } \\
\hline 3.1477 & 3 & Most of our projects are cost effective over time \\
\hline 3.0227 & 3 & Most of our projects are adaptable with minimum cost \\
\hline 3.1519 & 3 & Most of our projects are affordable to apply \\
\hline 3.2045 & 3 & Most of our projects had improved the use of local resources. \\
\hline 3.0568 & 3 & Most of our projects are energy efficient \\
\hline 3.0795 & 3 & Most of our projects are material efficient \\
\hline
\end{tabular}

\section{Non - Financial Sustainability Performance}

The highest mean score for non financial sustainability performance for the whole data set as perceived by the construction stakeholders was 3.1136 where the respondents believed that most of their project had optimise the land consumption.
The minimum scores was 2.8523 where the respondents believed that most of their project had reduced the green house emissions. In term of critically index, only 2 items be categorised at moderate level. Overall mean for the whole data set is 2.9756 which could be considered at mild level.

Table 1.3 - Mean Analysis for Non Financial Sustainability Performance

\begin{tabular}{|c|c|l|}
\hline $\begin{array}{c}\text { Mean Factor Score } \\
\text { Range }\end{array}$ & Criticality Index & \multicolumn{1}{|l}{ Items } \\
\hline 2.8523 & 2 & Most of our projects had reduce green house gas emissions \\
\hline 2.9659 & 2 & Most of our projects had improved the waste management process. \\
\hline 2.8977 & 2 & Most of our projects had improved the use of recycle and reuse reources \\
\hline 3.0455 & 3 & Most of our projects had minimize the pollution (noise, water and air) \\
\hline 3.1136 & 3 & Most of our projects had optimize the consumption of land \\
\hline 2.9886 & 2 & Most of our projects protect and enhanced biodiversity \\
\hline 2.9659 & 2 & Most of our projects had reduce transportation dependency \\
\hline
\end{tabular}




\section{Conclusion}

General objective was met through the accomplishments of the research. More importantly, the current level of sustainability performances were identified among the Malaysian construction stakeholders. The result of this study shows that the performance of financial sustainability is better than non financial sustainability. From the financial sustainability performances aspect, this study found that all the items can be classified at moderate level. However, for the non financial sustainability performance aspect, it can be classified at the mild level. Due to the current environment of Malaysia's construction industry, a few initiatives need to be taken to improve the current practices. These initiatives include :

a. Improved the waste management process;

b. Improved the use of recycle and reuse resources;

c. Improved the protection and enhancement of biodiversity and;

d. Reduce transportation dependency.

As mentioned earlier, to increase the consideration of sustainability, the construction stakeholders must be willing to change their attitudes and culture in exploring new territory and willing to adopt new ideas and practices especially regarding the environmental issues.

\section{Acknowledgements}

The authors would like to thank the Malaysian Ministry of Higher Education (MOHE) and Universiti Utara Malaysia (UUM) for providing the necessary funding to undertake this project. The authors are also appreciate the input provided by the industry practitioners who participated in the questionnaire survey.

\section{References}

Ashworth, A. \& Harvey, R. C. (1997). The Construction Industry of Great Britain, Newnes, Oxford, England; Boston.

Augenbroe, G. \& Pearce, A. R. (1998). 'Sustainable Construction in the United States of America A perspective to the year 2010,'

Azapagic, A. (2003). "Systems Approach to Corporate Sustainability: A General Management Framework," Process Safety and Environmental Protection, 81(5), 303316.

Azapagic, A. (2004). "Developing a Framework for Sustainable Development Indicators for the Mining and Minerals Industry," Journal of Cleaner Production, 12(6), 639-662.

Bakkens, W. (2003). "Realizing the Sector's Potential for Contributing to Sustainable Development," UNEP Industry and Environment. 26(2-3): 9-12.

Bansal, P. (2005). "Evolving Sustainability: A Longitudinal Study of Corporate Sustainable Development," Strategic Management Journal, 26: 197-218.

Blair, T. (2006). Climate Change - The UK Programme 2006, Norwich: TSO.

Chaharbaghi, K. \& Wills, R. (1999). "The Study and Practice of Sustainable Development," Engineering Management Journal, Vol.9, No. 1, Feb. 1999,Pp. 41-48.

Ding, G. K. C. (2005). "Developing a Multicriteria Approach for the Measurement of Sustainable Performance," Building Research \& Information, 33(1), 316.

Ding, G. K. C. (2008). "Sustainable Construction-The Role of Environmental Assessment Tools," Journal of Environmental Management, 86 451464(2008), 451-464. 
Gloet, M. (2006). "Knowledge Management and the Links to Hrm Developing Leadership and Management Capabilities to Support Sustainability," Management Research News, 29(7), 402-413.

Henriques, A. (2001). 'Sustainability, A Manager's Guide,' British Standards Institution, 2001.

Hill, R. C. \& Bowen, P. (1997). "Sustainable Construction: Principles and Framework for Attainment," Construction Management and Economics, 15, 223-239.

Kibert, C. J. (2005). "Sustainable Construction: Green Building Design and Delivery," John Wiley \& Sons, New York.

Lanthing, R. (1995). 'Sustainable Development and the Future of Construction,' CIB W82.

Levin, H. (1997). "Systematic Evaluation and Assessment of Building Environmental Performance (SEABEP)," Proc. Second International Conference on Buildings and the Environment, CSTB And CIB, 2, Paris, June, 3-10.

Liddle, B. T. (1994). 'Construction for Sustainability and the Sustainability of the Construction Industry,' Proceedings of the First International Conference on Sustainable Construction, CIB TG 16, C.J. Kibert, Ed., Tampa, FL, November 6-9.

Macozoma, D. S. (2001). 'Report - Building Deconstruction,' International Report, Prepared for International Council for Research and Innovation in Building and Construction (CIB).

Maylor, H. (1999). Project Management, 2 nd ed. London: Financial Times.

Mobey, A. \& Parker, D. (2002). "Risk Evaluation and Its Importance to Project Implementation," Int. J. Productivity and Performance Management, 51(4): Pp 202 208.

Ofori, G. (1992). "The Environment: The Fourth Construction Project Objective?,"
Construction Management \& Economics, 10 (5), 369-395.

Ofori, G., Briffett, C., Gang, G. \& Ranasinghe, M. (2000). "Impact of ISO 14000 on Construction Enterprises in Singapore," Construction Management and Economics, $18,935-947$.

Parkin, S. (2000). "Context and Drivers for Operationalizing Sustainable Development," Proceedings Of ICE, Vol. 138, Nov.2000, Pp.9-15.

Plessis, C. (2002). 'Agenda 21 for Sustainable Construction in Developing Countries, A Discussion Document,' CSIR Building and Construction Technoloy, Pretoria.

Raynsford, N. (2000). "Sustainable Construction: The Government's Role," Proceedings of ICE, Vol. 138, Nov. 2000, Pp.16-22.

Roodman, D. M. \& Lenssen, N. (1995). World Watch Report 124, A Building Revolution: How Ecology and Health Concerns Are Transforming Construction. World Watch Institute, March.

Shafii, F., Othman, M. Z. (2005). 'Sustainable Building and Construction in South-East Asia,' Proceedings of the Conference on Sustainable Building South-East Asia, Malaysia.

Watuka, Jennifer (2002). 'Sustainable Construction: An Investigation into the Awareness and Implementation of Sustainable Construction Practices in the Kenyan Construction Industry,' Unpublished Research Project, University of Nairobi.

WCED (1987). Our Common Future. Oxford: Oxford University Press.

Wells J (1986). The Construction Industry in Developing Countries: Alternative Strategies for Development, Beckenham, Croom Helm. 